\title{
Bootstrap Approach for Analyzing the Influence of Interpersonal Communication Skills on Science Performances
}

\author{
Umi Mahmudah $^{1} \&$ Siti Fatimah ${ }^{2}$ \\ ${ }^{1}$ Institut Agama Islam Negeri Pekalongan, Indonesia \\ ${ }^{2}$ Institut Agama Islam Nahdlatul Ulama Kebumen, Indonesia \\ Correspondence: Umi Mahmudah, Institut Agama Islam Negeri Pekalongan, Indonesia. \\ Email: umi.mahmudah@iainpekalongan.ac.id
}

Doi: 10.23918/ijsses.v8i1p137

\begin{abstract}
This study aims to analyze the influence of interpersonal communication skills on students' science performances. Moreover, gender and high school background are also analyzed. This study uses a nonparametric bootstrap for regression models. It allows us to avoid statistical assumption tests which usually must be done in the traditional regression estimation. Both qualitative and quantitative methods are used in this study. As many as $\mathbf{7 2}$ undergraduate students are used. All statistical results are performed using $\mathbf{R}$ program. The empirical results reveal that interpersonal communication skills affect students' science performance positively. The results also show gender and high school background have positive impact on science performance. Overall, the results reveal that bootstrap approach in regression produce better accuracy. This research implies the importance of interpersonal communication skills to be mastered by all students, so they can adapt properly during their education as well as graduating from school.
\end{abstract}

Keywords: Interpersonal, Communication, Science Performance, Bootstrap Regression

\section{Introduction}

Communication skills become one of the abilities that must be mastered by students to be able to compete globally in addition to critical thinking and problem-solving skills, creativity, and ability to work collaboratively. Communication is a process of exchanging information through verbal and non-verbal methods (Iksan et al., 2012). Communication also involves the exchange of ideas, opinions, and information by using specific goals. The most commonly used communication method is verbal, i.e. using certain languages, which is a two-way process and by providing feedbacks. Communication is one of the most essential interpersonal processes in an organization (Sabanci et al., 2016). Meanwhile, Mahajan defines effective communication as the most important tool to achieve the ultimate goal. There are at least four techniques that are very helpful for improving communication skills, namely listening, speaking, reading and writing (Mahajan, 2015). Figure 1 shows the proportion of people in daily communication using these techniques (Mahajan, 2015).

Received: January 22, 2021

Accepted: March 12, 2021

Mahmudah, U., \& Fatimah, S. (2021). Bootstrap Approach for Analyzing the Influence of Interpersonal Communication Skills on Science Performances. International Journal of Social Sciences \& Educational Studies, 891), 137-148. 


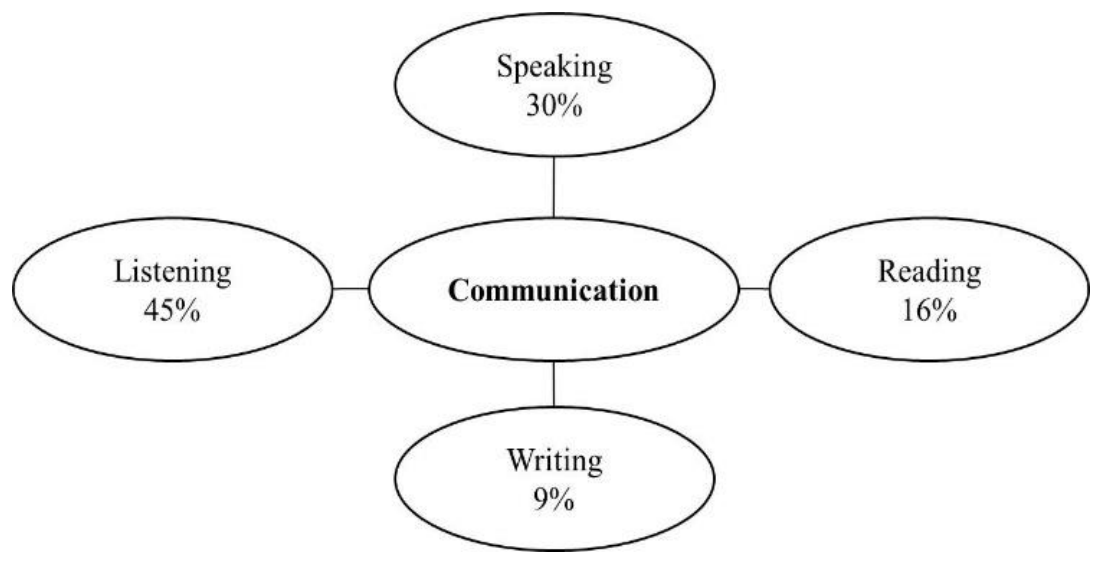

Figure1: Communication time spent by an individual in a day (Source: Mahajan, 2015)

Communication skills are fundamental for every individual to transfer information to other individuals. Good communication skills provide conveniences for someone to absorb information properly to avoid the possibility of miscommunication. Communication skills are fundamental for every individual to transfer information to other individuals. Good communication skills provide conveniences for someone to absorb information properly to avoid the possibility of miscommunication.

A preliminary observation shows that most students use technology media to communicate. Nearly $95 \%$ of the students prefer to communicate using mobile phones, especially the WhatsApp (WA) application. Further, this preliminary observation also indicates that they use the Google engine for searching various kinds of information. Then, it is found that only about $20 \%$ of the students are happy to discuss and meet in person to communicate. This is strengthened by a survey conducted by the Ministry of Communication and Information of the Republic of Indonesia in 2018 which show that the use of social media especially WA reached $65.10 \%$, where the most respondents are in the age group of 20-29 years. Therefore, it is apparent that students tend to choose mobile phones to communicate with others. However, this tendency has an impact on students by decreasing interpersonal communication skills. A survey reveals that students who have poor communication skills hinder the achievement of goals and expectations (Okoro et al., 2017). Therefore, it is very important for college graduates and job seekers to possess communication skill because appropriate language, courtesy and professional phrases during interaction create a good and beneficial impression.

One of the essential communication skills is interpersonal communication, which is one of the multiple intelligences (Gardner, 1994). He defines interpersonal communication skills as the ability to understand other people's feelings, motivations, and intentions in order to respond effectively (Gardner, 2008). Interpersonal communication is described as communication between two individuals, where they interact physically and give reciprocal feedback (Murtiningsih et al., 2019). There are four dimensions of interpersonal skills including dimensions of empathy and active listening, feedback, effectiveness (openness, clarity, transparency), and trust (Sabanci et al., 2016). Interpersonal skills require effective communication, empathy, active listening, a culture of competence and professionalism (Skinner et al., 2016). 
Many researchers believe these skills can bring success. Individuals who excel in interpersonal intelligence have good achievements as teachers, social workers, politicians or anyone who must interact with the community (Gangadevi \& Ravi, 2014). Furthermore, Social interaction may be hampered if individuals do not have good interpersonal communication. This skill has a large role in the success of delivering interpersonal messages. When communicators use language and expressions that are not appropriate with the contents of the message can affect the way the communicant responds to the message. When someone expresses a message using inappropriate language, there is possibility of miscommunication. In fact, other people may face difficulties in giving a good response or feedback (Khodijah, 2018).

There are studies that have examined interpersonal communication skills in education. There are factors that affect academic achievement, where one of them is interpersonal communication skills. Interpersonal communication skills greatly affect academic achievement significantly. The quality of interpersonal interactions increases academic achievement (Tsai \& Liu, 2015). High-quality interpersonal relationships encourage higher academic achievement (Kiuru et al., 2020; Upadyaya \& Salmela-Aro, 2013). Positive communication helps establish a stable environment while coping with student stress. Thus, increasing interpersonal communication is important for students to maintain academic achievement (Seo \& Kwon, 2016). A study reports that there is a significant relationship between interpersonal communication skills and teacher work ethics (Murtiningsih et al., 2019). Furthermore, a report mentions the importance of interpersonal communication skills between teacher and students on student achievement. There is tangible evidences that it has a significant influence on student academic achievement (Elegbe, 2018). Effective interpersonal communication skills are essential to graduate student success (Wilkins et al., 2015).

Studies on interpersonal communication skills and their relationship to student achievement in Indonesia have been reviewed. The low interpersonal communication skills of students can make it difficult for them to adapt to the campus environment (Ariyani \& Hadiani, 2020). Consequently, it may interfere with their academic performance. Thus, students who have better interpersonal skills also tend to have better academic achievement (Ariyani \& Hadiani, 2020). In addition, a teacher's interpersonal communication skills are also reported to affect student academic achievement (Nurhadi \& Niswah, 2019). Students who have interpersonal intelligence are believed to be able to perform all stages of solving mathematical problems (Wicaksono, 2020). A study reports that playing science is able to develop children's interpersonal intelligence (Ayunita, 2016).

Even though it has been researched in Indonesia, however, research on the same topic among students in Indonesia is still limited, especially on the science achievement. Currently, science and technology have a vital role in all fields. So, the ability of science is a necessity in increasing human resources who are able to compete globally (Mahmudah et al., 2020). Thus, it is important to conduct a more in-depth study of students' interpersonal communication and its relation to their science performance. This is because of the importance of this skill for students to prepare themselves for life not only while studying on campus but also in the workplace. Unfortunately, college graduates tend to lack interpersonal skills when entering the workforce (Flores et al., 2012; Lolli, 2013). In addition, this study also provides empirical evidence of the 
importance of interpersonal communication skills for improving Indonesian human resources to be able to compete globally.

This study applies bootstrap approach in regression model. It is well-known that the ordinary least squares (OLS) method is the most used to estimate the regression coefficients. However, the OLS method tends to produce misleading estimation results (Fox \& Weisberg, 2012, 2018; Mahmudah et al., 2017). There are various ways to overcome problems when using the OLS method in estimating regression model. One of them is by applying a non-parametric bootstrap approach on regression model. The bootstrap approach is widely used since it was introduced by Efron. It is a non-parametric method by using sample replication (Efron, 1979). Bootstrap approach on regression model produces more accurate results (Chernick \& LaBudde, 2014; Eck, 2018; Fox \& Weisberg, 2012, 2018). Bootstrap hypothesis testing in regression can be used by using many regressors (Richard, 2019).

\section{Method}

This research uses a mixed approach, namely a combination of qualitative and quantitative methods (Creswell \& Creswell, 2018). A qualitative approach is carried out by observing student behavior during the learning process. The qualitative approach is focused on getting a deeper picture of students' interpersonal communication skills. Therefore, the observation made by the lecturer during the learning process for one full semester. Meanwhile, the quantitative approach is carried out by distributing questionnaires to 72 randomly selected students, which are students of pre-service teacher in primary teacher education program at the Sebelas Maret University, Indonesia. The distribution of questionnaires is carried out on 19-25 October 2020 using an online survey.

The questionnaire instrument of interpersonal communication skill variables are measured using four indicators, which are empathy and active listening, feedback, effectiveness, and trust (Sabanci et al., 2016). Each indicator is measured using four statement items that must be answered by the respondents. The items on the questionnaire use a Likert scale of 1 to 4 . Meanwhile, students' science performance is measured using their final grade in the science course. This grade includes the scores of attitudes, assignments, activeness, midterm, and final semester. Therefore, the hypotheses used in this study are as follows:

H0: There is no significant effect of students' interpersonal communication skills on their science performance.

H1: There is significant effect of students' interpersonal communication skills on their science performance.

These hypotheses are used as the main basis for making the conclusions of this study. To analyze the impact of interpersonal communication skill on students' science performance, this study applies bootstrap approach on regression method. Because this approach is nonparametric, the assumption tests that should be performed on the OLS method are unnecessary. The bootstrap approach to the regression model can be explained as follows (Efron \& Tibshirani, 1994). Let $x_{i}$ represent the explanatory variables where $i=$ $1,2, \ldots n$. Meanwhile, the response variable is defined by $y_{i}$. By using bootstrap approach, suppose each pair of $\left(x_{i}, y_{i}\right)$ produces new samples $x_{1}^{*}=\left(x_{11}^{*}, x_{21}^{*}, \ldots, x_{n 1}^{*}\right), x_{2}^{*}=\left(x_{12}^{*}, x_{22}^{*}, \ldots, x_{n 2}^{*}\right), \ldots, x_{N}^{*}=$ 
$\left(x_{1 N}^{*}, x_{2 N}^{*}, \ldots, x_{n N}^{*}\right)$. Suppose that the estimator of the new samples is defined by $\varphi_{N}\left(x_{i}\right)=$ $\varphi_{N}\left(x_{1}, x_{2}, \ldots, x_{n}\right)$. The general steps to estimate bootstrap regression model are as follows (Efron \& Tibshirani, 1994):

Step 1: Fitting the regression model and the fitted values $\hat{y}_{i}$ as well as the residuals $\hat{e}_{i}=y_{i}-\hat{y}_{i}$.

Step 2: For each pair of $\left(x_{i}, y_{i}\right)$, estimating $y_{i}^{*}=\hat{y}_{i}+\hat{e}_{j}$ by using a randomly re-sampled residual, $\hat{e}_{j}$ to the response variable $y_{i}$.

Step 3: Refitting the model by using the new response variables $y_{i}^{*}$.

Step 4: Repeating step 2 to step 3 B times.

This study applies these steps of bootstrap regression to obtain the empirical results by using R program.

\section{Results and Discussion}

\subsection{Descriptive Statistics}

To see how interpersonal communication can affect students' science performance, this study uses bootstrap approach on regression model. A total number of respondents are 72 undergraduate students of pre-service teacher in primary teacher education program.

The general description of the data used in this study can be described as follows. The average age of the respondents is 19 years, whereas the youngest respondent is 18 years old. Meanwhile, the oldest respondent's age is 21 years old. Most respondents are female, which is 63 respondents (87.5\%) compare to male respondents by $12.5 \%$ ( 9 respondents). Not surprisingly, the diversity of respondents by sex appears unequal. This is because all respondents are prospective elementary school teachers.

Then, Figure 1 shows the general description of the respondents based on their high school education background. There are three types of high school backgrounds depicted in this study, which are senior high school, vocational high school, and Islamic-based high school (madrasah aliyah). It is important to point out that madrasah aliyah is high school, where management is carried out under the Ministry of Religion.

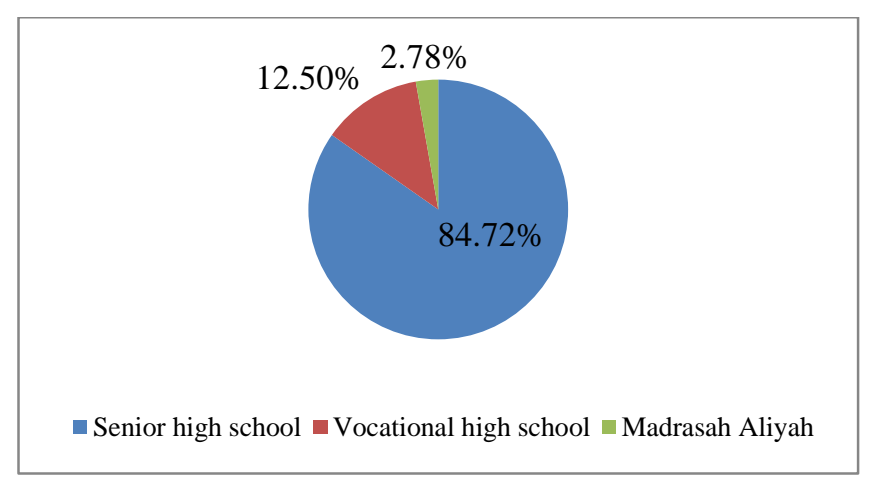

Figure 2: High school background 
Based on figure 2, it can be clearly seen that most respondents came from senior high school, which is equal to $84.7 \%$ followed by students from Vocational high school and madrasah aliyah as many as $12.5 \%$ and $2.8 \%$, respectively.

As mentioned earlier, interpersonal communication skills consist of four aspects, namely empathy and active listening, feedback, effectiveness (openness, clarity, transparency), and trust. Analysis of the questionnaire indicates students' interpersonal communication skills are quite good, which is $75.33 \%$. Figure 3 shows each indicator of students' interpersonal skills.

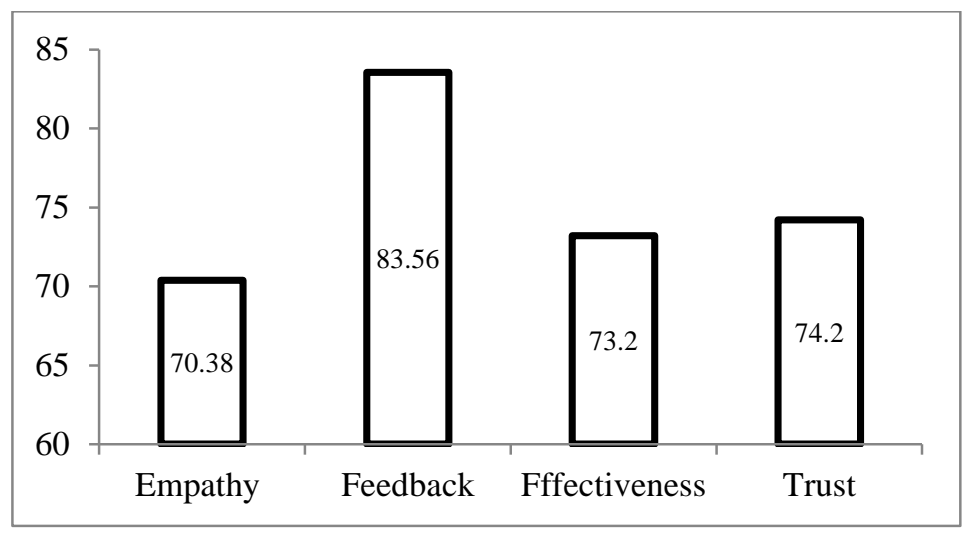

Figure 3: Students' interpersonal skills

From Figure 3, it is apparent that the feedback aspect on students' interpersonal communication skills shows the highest category compared to other aspects, which is $83.56 \%$. Meanwhile, the lowest aspect is empathy, which is equal to $70.38 \%$. Furthermore, the aspects of effectiveness and trust produce a score of 73.2 and 74.2, respectively. It comes as no surprise that the aspect of feedback produces the highest score because students are adult individuals who have critical thinking skills therefore students tend to be happy in providing feedbacks as well as expressing opinions. However, their opinions and feedbacks are sometimes still based on assumptions without validity of literatures. Unfortunately, it also still tends to strike down other people's opinion which caused poor empathy. Furthermore, interview results show that most students prefer to expressing their opinions rather than listening. This is because students do not like to be criticized and find it hard to accept objections from others. These results are in accordance with the research conducted by Sabanci that report the feedback aspect has the highest average while the empathy aspect is the lowest aspect (Sabanci et al., 2016).

These results are also supported by observations made by the lecturers, which can be described as follows. Student communication skills can be said to be quite good, where many students provide feedback in ongoing class discussions. The feedback is not only given by students to questions or statements given by the lecturer but also to their peers. This indicates their willingness to play an active role in the learning process in the classroom. This result is also supported by previous research which reported that student activeness is one of the good characteristics of their interpersonal communication. The activeness of students in providing feedback is an indication of their good interpersonal communication skills (Sabanci et al., 2016). The observations also indicated that the feedback aspect on students' interpersonal communication skills shows the highest category compared to other aspects. Meanwhile, the lowest aspect 
is their empathy. These results are in accordance with previous research that report the feedback aspect has the highest average while the empathy aspect is the lowest aspect (Sabanci et al., 2016).

It comes as no surprise that the aspect of feedback produces the highest category because they are adult individuals who have critical thinking skills. Therefore, students tend to be happy in providing feedbacks as well as expressing opinions during discussion sessions (Hyland, 2000; Newton et al., 1999). However, the observations also reveal their opinions and feedbacks are sometimes still based on assumptions without validity of literatures. So, there is an impression that students give feedback carelessly. They do not see the need to think before giving feedback. As a result, their arguments during the discussion tend to be of less quality, less relevant to the topic of discussion, and lack empathy for discussion partners.

From the lecturers 'observations, it is also known that students prefer to turn off classmates' arguments in discussions. They do look happy to give feedback, but the way it is conveyed is less empathetic when arguing with peers. This is one of the reasons why the aspects of empathy and active listening are the categories with the lowest scores according to table 3. Conversely, when they provide arguments to the lecturer, they show empathy and respect that is not visible when they interact with classmates. So, students tend to use polite and orderly language with better body language when interacting with lecturers. However, their attitudes are inversely proportional when arguing with classmates. Furthermore, observation results indicate students prefer to expressing their opinions rather than listening. This is because students do not like to be criticized and find it hard to accept objections from others. However, their willingness and courageous to provide feedback on an argument is a good thing and should be appreciated.

Based on lecturers' observations, it is also known that students who have a better sense of empathy are those from madrasah aliyah. On the other hand, students who tend to like to provide feedback in class are those from high school or vocational high schools and rarely from madrasah aliyah. So, it can be said that students from madrasah aliyah are more likely to be inactive in the discussion process but have better attitudes or empathy. This may be because they get more material about religiosity, where religious values promote empathy for humans.

\subsection{Hypothesis Testing}

This section provides a hypothesis analysis to build decisions based on the hypotheses that have been previously offered. In addition to students' interpersonal communication skills, this study also analyzes the influence of their gender and high school background on science performance. Nonetheless, in-depth discussions focus on the influence of students' interpersonal communication on their science performance.

To use the bootstrap approach on regression models then this study uses the number of bootstrap replicates of the regression coefficients $\mathrm{B}=100,500$, and 1000. Table 1 shows the results of bootstrapped regression model for analyzing the influence of interpersonal communication skills (X1), gender (X2), and high school background (X3) on students' science performances. 
Table 1: Estimation Results

\begin{tabular}{|c|c|c|c|c|c|c|c|}
\hline Coefficients & Estimates & \multicolumn{2}{|c|}{$\mathrm{B}=100$} & \multicolumn{2}{c|}{$\mathrm{B}=500$} & \multicolumn{2}{c|}{$\mathrm{B}=1000$} \\
\cline { 3 - 8 } & & bias & $\begin{array}{c}\text { std. } \\
\text { error }\end{array}$ & bias & $\begin{array}{c}\text { std. } \\
\text { error }\end{array}$ & bias & $\begin{array}{c}\text { std. } \\
\text { error }\end{array}$ \\
\hline Constant & 50.776 & 0.503 & 6.062 & 0.675 & 6.608 & -0.026 & 6.946 \\
\hline$X_{1}$ & 5.964 & 0.021 & 1.905 & -0.15 & 2.072 & 0.053 & 2.201 \\
\hline$X_{2}$ & 5.117 & 0.048 & 1.019 & 0.016 & 1.047 & 0.027 & 1.061 \\
\hline$X_{3}$ & 1.753 & -0.467 & 1.345 & -0.171 & 1.458 & -0.181 & 1.395 \\
\hline
\end{tabular}

Table 2 presents the original sample value of ordinary least squares (OLS) regression along with both the bootstrap estimates of bias and standard errors. It is important to note that the bootstrapped bias estimates are the difference between the average of statistic value from bootstrap approach and its original value. Meanwhile, the bootstrapped standard errors are calculated as the standard deviation of the bootstrap replicates. Based on table 2, the estimation results of the OLS method are indicated by estimates where all the independent's variables, which are interpersonal communication skills (X1), gender (X2), and high school background (X3) have positive impact on students' science performances. The regression coefficients for these independent variables are 5.964, 5.117 and 1.753, respectively.

From Table 1, it is apparent that bootstrap approach on regression model produces good results, where the estimation bias shows a very small value for all the number of replications B. In addition, the values for standard errors also show relatively small numbers, which indicate better estimation. This result is consistent with previous researches which state that the bootstrap approach provides better results for estimating the regression coefficients (Chernick \& LaBudde, 2014; Watagoda \& Olive, 2019). Furthermore, the regression coefficients from the bootstrap analysis are presented in Table 2.

Table 2: Bootstrapped Regression Coefficients

\begin{tabular}{|c|c|c|c|c|}
\hline Variables & OLS & $\mathrm{B}=100$ & $\mathrm{~B}=500$ & $\mathrm{~B}=1000$ \\
\hline Constant & 50.776 & 51.279 & 51.451 & 50.750 \\
\hline$X_{1}$ & 5.964 & 5.985 & 5.814 & 6.017 \\
\hline$X_{2}$ & 5.117 & 5.165 & 5.133 & 5.144 \\
\hline$X_{3}$ & 1.753 & 1.286 & 1.582 & 1.572 \\
\hline
\end{tabular}

Table 2 shows that the bootstrap approach in regression model produces slightly different regression coefficients compare to the OLS regression. For the replication number $B=100$, the bootstrapped regression coefficients of interpersonal communication skills (X1), gender (X2), and high school background (X3) are 5.985, 5.165, and 1.286, respectively. Therefore, by using the replication number $\mathrm{B}=100$ then the regression model can be written as follows.

$$
Y_{B=100}=51.279+5.985 X_{1}+5.165 X_{2}+1.286 X_{3}+e
$$


Furthermore, based on table 3, the regression models for the replication number $\mathrm{B}=500$ and $\mathrm{B}=1000$ can be written as follows.

$$
Y_{B=500}=51.451+5.814 X_{1}+5.133 X_{2}+1.582 X_{3}+e
$$

And

$$
Y_{B=1000}=50.750+6.017 X_{1}+5.144 X_{2}+1.572 X_{3}+e
$$

Therefore, it can be concluded that the bootstrap approach is more appropriate to estimate the impact of interpersonal communication skills, gender, and high school background on the student science performances due to its power to produce better estimates with higher accuracy (Chernick \& LaBudde, 2014; Eck, 2018; Fox \& Weisberg, 2018).

The coefficient regression of gender variable (X2) is 5.165 which mean that students' science performances are predicted to rise by 5.165 points when all other variables are constant. It is important to note that the codification of the gender variable is 1 for male students and 2 for female students therefore it is safe to conclude that the prediction value for females' students' science performances will be 5 points higher than for male students. Observations by the lecturers reveal that not only female students appear to be more motivated to learn mathematics and science but also, they produce better scores in mathematics and science than male students. In addition, female students also tend to have better attitudes towards mathematics and science. These results are also consistent with previous reports. Based on the OECD report on PISA 2018 it is found that Indonesian female students outperform male students in mathematics by 10 points. Then, they also outperform male students in science by 7 points (OECD, 2019). In contrast, female students in Hong Kong and China are reported to have lower performance in science and less positive attitudes toward science (Lau \& Ho, 2020).

Meanwhile, the variable of high school background (X3) produces a regression coefficient of 1.286 which means that it is predicted that there will be an increase in students' science performances of 1.286 units when this variable increase one unit. The results based on lecturer' observations indicate that students from high schools outperform those from vocational schools and mardasah aliyah in mathematics and science. They look more comfortable learning mathematics and science. Besides, their positive attitude towards science is also more visible. They may have more knowledge of mathematics and science when studying in high school. This result is not surprising because vocational high schools tend to provide more skills according to their respective majors, so they tend to pay less attention to mathematics and science. Meanwhile, students of madrasah aliyah tend to prioritize religious knowledge and values so that mathematics and science are less attractive to them.

Furthermore, from table 3 it can be clearly seen that for the replication number $B=100$, the regression coefficient of interpersonal communications skills (X1) is equal to 5.985 which mean that for each increase of one unit in this variable, it can be expected that students' science performances increase by 5.985 units when all other variables are constant. These results are supported by previous studies which report the influence of students' interpersonal communication skills on academic performance (Elegbe, 2018; Kiuru et al., 2020; Seo \& Kwon, 2016; Tsai \& Liu, 2015). Individuals who can adapt during their education have a long-term positive impact not only on academic achievement but also on their mental health. There is a 
reciprocal relationship between the quality of interpersonal relationships and school welfare, where both of these constructs affect academic achievement (Kiuru et al., 2020).

The quality of interpersonal relationships and the school welfare of students to influence academic achievement during education are crucial. These successful adaptations have a long-term impact on academic outcomes (Kiuru et al., 2020; Upadyaya \& Salmela-Aro, 2013). This may be because students' interpersonal skills are able to reduce stress when facing difficult situations during their education so that they can increase their focus as well as their attention to the given material and assignments (Kiuru et al., 2014; Upadyaya \& Salmela-Aro, 2013). Thus, interpersonal communication skills become a necessity for all students at all levels of education to adapt to the educational environment. In addition, this ability is also able to provide excellent provisions for students when plunging into the workplaces which require high-level communication skills.

Furthermore, the results of this study also do not contradict reports from previous studies which state that interpersonal communication can improve students' science performance. Students with good interpersonal skills are found to be able to solve mathematics problems (Wicaksono, 2020). Then, there is a positive relationship between playing science and students' interpersonal skills, including being tolerant, adapting, recognizing emotions, and showing emotional reactions (Ayunita, 2016).

Broadly speaking, interpersonal communications skills are very useful for students in improving as well as maintaining their science performance. It is well-known that workforce not only requires academic values but also soft skills, such as communications skills. Consequently, all school stakeholders are required to be able to provide and develop interpersonal communication skills for all students. Thus, their graduates can adapt appropriately to be able to develop their abilities and values. This indirectly improves the quality of Indonesia's human resources so that they can compete globally.

\section{Conclusions}

This study investigates how students' interpersonal communication skills improve their science performances. Bootstrap approach is applied in regression models to provide better accuracy of the estimation results. There are four aspects of interpersonal communication skills that are used in this study, namely empathy and active listening, feedback, effectiveness, and trust. Overall, the empirical results reveal that interpersonal communication skills can improve students' science performance. The results also suggest that students have good critical thinking skills so that they like to give feedbacks and the expressing their opinions. Unfortunately, the results also indicate that students tend to have less empathy. Furthermore, the variable of gender also influences students' science performance positively. Then, high school background of students has also a positive impact. More comprehensive research can be done to see students' interpersonal communication skills in a wider range, such as their career success after graduating from school.

\section{References}

Ariyani, E. D., \& Hadiani, D. (2020). Keterampilan Komunikasi Interpersonal antar Mahasiswa dan Hubungannya dengan Capaian Prestasi Akademik. JSHP: Jurnal Sosial Humaniora Dan Pendidikan, 4(2), 141-149. 
Ayunita, V. (2016). Pengembangan Kecerdasan Interpersonal Anak Usia Dini Melalui Bermain Sains Di Tk IT Al-Madani Simeulue. ETD Unsyiah, 1(4).

Chernick, M. R., \& LaBudde, R. A. (2014). An introduction to bootstrap methods with applications to R. John Wiley \& Sons.

Creswell, J. W., \& Creswell, D. J. (2018). Research design: Qualitative, quantitative, and mixed methods approaches. United Kingdom, UK. SAGE Publications, Inc.

Eck, D. J. (2018). Bootstrapping for multivariate linear regression models. Statistics \& Probability Letters, 134, 141-149. https://doi.org/10.1016/j.spl.2017.11.001

Efron, B. (1979). Bootstrap Methods: Another Look at the Jackknife. The Annals of Statistics, 7(1), 126. https://doi.org/10.1214/aos/1176344552

Efron, B., \& Tibshirani, R. J. (1994). An introduction to the bootstrap. CRC press.

Elegbe, O. (2018). Lecturers-Students' Interpersonal Communication: Implication for Students' Academic Learning. Huria: Journal of the Open University of Tanzania, 25(1), 28-54.

Flores, K. L., Matkin, G. S., Burbach, M. E., Quinn, C. E., \& Harding, H. (2012). Deficient critical thinking skills among college graduates: Implications for leadership. Educational Philosophy and Theory, 44(2), 212-230.

Fox, J., \& Weisberg, S. (2012). Bootstrapping regression models in R. An appendix to An R companion to applied regression. Unpublished Manuscript. Accessed at Http://Socserv. Mcmaster. ca/Jfox/Books/Companion/Appendix. Html.

Fox, J., \& Weisberg, S. (2018). An R companion to applied regression. Sage publications.

Gangadevi, R., \& Ravi, D. (2014). Multiple intelligence based curriculum to enhance inclusive education to bring out human potential. International Journal of Advance Research, 2(8), 619-626.

Gardner, H. E. (1994). Intelligences in Theory and Practice: A Response to Elliot W. Eisner, Robert J. Sternberg, and Henry M. Levin. Teachers College Record, 95(4), 576-583.

Gardner, H. E. (2008). Multiple intelligences: New horizons in theory and practice. Basic books.

Hyland, F. (2000). ESL writers and feedback: Giving more autonomy to students. Language Teaching Research, 4(1), 33-54.

Iksan, Z. H., Zakaria, E., Meerah, T. S. M., Osman, K., Lian, D. K. C., Mahmud, S. N. D., \& Krish, P. (2012). Communication skills among university students. Procedia-Social and Behavioral Sciences, 59, 71-76.

Khodijah, S. (2018). Strategy for Increasing The Students' Interpersonal Communication Skills through Problem-Based Learning. International Journal of Educational Research Review, 3(4), 150 158.

Kiuru, N., Pakarinen, E., Vasalampi, K., Silinskas, G., Aunola, K., Poikkeus, A.-M., Metsäpelto, R.-L., Lerkkanen, M.-K., \& Nurmi, J.-E. (2014). Task-focused behavior mediates the associations between supportive interpersonal environments and students' academic performance. Psychological Science, 25(4), 1018-1024.

Kiuru, N., Wang, M.-T., Salmela-Aro, K., Kannas, L., Ahonen, T., \& Hirvonen, R. (2020). Associations between adolescents' interpersonal relationships, school well-being, and academic achievement during educational transitions. Journal of Youth and Adolescence, 49(5), 10571072.

Lau, K.-C., \& Ho, S.-C. E. (2020). Attitudes Towards Science, Teaching Practices, and Science Performance in PISA 2015: Multilevel Analysis of the Chinese and Western Top Performers. Research in Science Education, 1-12.

Lolli, J. C. (2013). Interpersonal communication skills and the young hospitality leader: Are they prepared? International Journal of Hospitality Management, 32, 295-298.

Mahajan, R. (2015). The Key role of communication skills in the life of professionals. IOSR Journal of Humanities and Social Science (IOSR-JHSS), 20(12), 36-39. 
Mahmudah, U., Chamdani, M., Tarmidzi, T., \& Fatimah, S. (2020). Robust regression for estimating the impact of student's social behaviors on scientific literacy. Cakrawala Pendidikan, 39(2), 293304. https://doi.org/10.21831/cp.v39i2.29842

Mahmudah, U., Suhartono, \& Fatimah, S. (2017). A robust approach to analyzing the factors influencing quality education in Indonesia. New Educational Review, 49(3), 77-90. https://doi.org/10.15804/tner.2017.49.3.06

Murtiningsih, M., Kristiawan, M., \& Lian, B. (2019). The Correlation Between Supervision of Headmaster and Interpersonal Communication With Work Ethos of the Teacher. European Journal of Education Studies.

Newton, P., Driver, R., \& Osborne, J. (1999). The place of argumentation in the pedagogy of school science. International Journal of Science Education, 21(5), 553-576.

Nurhadi, A., \& Niswah, F. (2019). Penerapan Komunikasi Interpersonal Tenaga Pendidik dalam Pencapaian Prestasi Belajar Siswa di MTs Nahdliyatul Islamiyah Blumbungan Larangan Pamekasan. AL-FIKRAH: Jurnal Studi Ilmu Pendidikan Dan Keislaman, 2(1), 1-20.

OECD. (2019). Programme for International Students Assessment (PISA) Results from PISA 2018: Indonesia-Country Note. https://www.oecd.org/pisa/publications/PISA2018_CN_IDN.pdf

Okoro, E., Washington, M. C., \& Thomas, O. (2017). The impact of interpersonal communication skills on organizational effectiveness and social self-efficacy: A synthesis. International Journal of Language and Linguistics, 4(3), 28-32.

Richard, P. (2019). Residual bootstrap tests in linear models with many regressors. Journal of Econometrics, 208(2), 367-394.

Sabanci, A., Sahin, A., \& Özdemir, İ. (2016). Interpersonal Communication Skills of the Leaders of Inspection Groups in Turkey. Online Submission, 5(4), 148-159.

Seo, K., \& Kwon, M. (2016). Study on the Effects of Interpersonal-Communication Competence and Family Communication Patterns on Academic Resilience. Indian Journal of Science and Technology, 9, 40.

Skinner, K. L., Hyde, S. J., \& McPherson, K. (2016). Improving Students' Interpersonal Skills through Experiential Small Group Learning. Journal of Learning Design, 9(1), 21-36.

Tsai, H.-C., \& Liu, S.-H. (2015). Relationships between time-management skills, Facebook interpersonal skills and academic achievement among junior high school students. Social Psychology of Education, 18(3), 503-516.

Upadyaya, K., \& Salmela-Aro, K. (2013). Development of school engagement in association with academic success and well-being in varying social contexts: a review of empirical research. European Psychologist, 18(2), 136.

Watagoda, P. L. C. R., \& Olive, D. J. (2019). Bootstrapping multiple linear regression after variable selection. Statistical Papers, 1-20. https://doi.org/10.1007/s00362-019-01108-9

Wicaksono, A. (2020). Profil Pemecahan Masalah Matematika Siswa SMP Dengan Kecerdasan Interpersonal Ditinjau Berdasarkan Gender. Koordinat Jurnal Pembelajaran Matematika Dan Sains, 1(1), 39-51.

Wilkins, K. G., Bernstein, B. L., \& Bekki, J. M. (2015). Measuring communication skills: The STEM interpersonal communication skills assessment battery. Journal of Engineering Education, 104(4), 433-453. 